\title{
Ethnic Pedagogical Knowledge \\ (Expansion of Content on the Materials \\ of the Republic of Tuva)
}

\author{
Svetlana Ya. Oorzhak \\ and Kherel-ool D.-N. Oorzhak* \\ Tuvan State University
}

36 Lenin Str., Kyzyl, Republic Tuva, 667000, Russia

Received 15.10.2018, received in revised form 16.11.2018, accepted 30.11.2018

Ethnic pedagogical knowledge in its content covers a set of knowledge in the field of ethnic pedagogy beginning with its subject - folk pedagogy and its origins, as well as knowledge in the field of many disciplines. The authors of the article assume that in the conditions of ethnic pedagogical education of the Republic of Tuva, the tasks of expanding the content of ethnic pedagogical knowledge remain relevant.

Keywords: ethno-pedagogy, ethno-pedagogical knowledge, formation of ethnic pedagogical knowledge, expansion and comprehension of their content.

Research area: culturology.

Citation: Oorzhak, S.Ya., Oorzhak Kh.D.-N. (2018). Ethnic pedagogical knowledge (expansion of content on the materials of the Republic of Tuva). J. Sib. Fed. Univ. Humanit. soc. sci., 12(2), 302-309. DOI: 10.17516/1997-1370-0364.

Many researchers consider ethnic pedagogical knowledge in their works (K.Zh. Kozhakhmetova, M.Kh. Mal'sagova, G.V. Nezdemkovskaya, V.Yu. Shtykareva and others). They deals with its content, which covers a complex of knowledge in the field of ethnic pedagogy and other fields.

The relevance of this article is connected with the need to understand the content of ethnic pedagogical knowledge in the process of ethnic pedagogization of education. The problem of expanding the content of ethnic pedagogical knowledge is considered as interdisciplinary, aimed at practical application of ethnic pedagogical studies.

(c) Siberian Federal University. All rights reserved

* Corresponding author E-mail address: herel-ool@mail.ru

This work is licensed under a Creative Commons Attribution-NonCommercial 4.0 International License (CC BY-NC 4.0). 
The object of the research is the content of ethnic pedagogical knowledge as an integral basis of ethnic pedagogical studies.

The objective of the research is to study the expansion of the content of ethnic pedagogical knowledge. In the course of the research we applied theoretical and empirical research methods.

The methodological basis of the study is a cultural approach. The theoretical foundations of the research are the works of the classics of pedagogy and modern scholars, including those in the field of methodology of ethnic pedagogical research. The novelty of the research has a methodological and scientific-methodological value in the process of teaching the course of ethnic pedagogy (in the context of higher education of the Republic of Tyva).

The analysis of scientific and pedagogical literature shows that ethnic pedagogical knowledge is considered as knowledge associated with theoretical knowledge and ethnic pedagogical activity. "The development of ethnic pedagogy, like any other science, began with the birth of the first ethnic pedagogical thoughts, the simplest ethnic pedagogical knowledge to theoretical and methodological concepts and justifications" (Nezdemkovskaya, 2011a: 2). "Ethnic pedagogy is an interdisciplinary branch of scientific and pedagogical knowledge. Interdisciplinary research is a way of organizing research involving interaction in the study of the same object by representatives of various disciplines ... Interdisciplinary research is considered primarily as a problem of research practice and transfer of its results into a knowledge system" (Nezdemkovskaya, 2011a: 3).

The studies note that "there is an increased interest for ethnicity observed lately, the importance of ethnic pedagogical knowledge in the modern society and the system of education is increased". V.Yu. Shtykareva outlines motivational-value-based, cognitive and managerial criteria as the criteria of the ethnic pedagogical competence of a future teacher (Shtykareva, 2005). Ethnic pedagogy demonstrates deep roots of ethnic pedagogical knowledge, which creates the basis for expanding its content at the modern stage of education development.

G.V. Nezdemkovskaya has analysed the formation of ethnic pedagogy in Russia beginning with the empirical stage. This analysis shows that the empirical educational experience accumulated during this period includes elements of ethnic pedagogical knowledge...". According to the author, ethnic pedagogical knowledge is a synthesis of folk and theoretical research. It is noted that "...objective scientific and practical prerequisites (anthropological, socio-economic, cultural, ethnological, historical and 
pedagogical, etc.) contributed to the emergence of ethnic pedagogical knowledge". The study showed that "the content of ethnic pedagogical knowledge includes the concepts about reality and general ethnic picture of the world, the diversity and specificity of traditional ethnic cultures and their interaction; ... about the relationship of a person to himself, family members, other people, etc." (Nezdemkovskaya, 2011b: 10). Each of this concepts relates to this or that field of knowledge. In the process of study and determination of the content of ethnic pedagogical knowledge such general research as analysis and synthesis are applied.

The content of ethnic pedagogical knowledge is also reflected in the study of M.Kh. Mal'sagova, which "has determined the regularities of ethnic pedagogical knowledge", and their forms (Mal'sagova, 2014: 15). The author thinks that “... the forms of ethnic pedagogical knowledge include ordinary-practical, playful, personal, folk pedagogy. If they are underestimated, this leads to ignorance of methodological principles of objectivity and historical order...". The author considers the content of these forms.

Expansion of the content of ethnic pedagogical knowledge is interdependent on ethnic pedagogical activity (V.Yu. Shtykareva), synthesis of folk and theoretical research (G.V. Nezdemkovskaya), cognitive and educational value of a specific ethnos in the pedagogical culture (K.Zh. Kozhakhmetova), patterns of ethnic pedagogical knowledge, and also its forms (M.Kh. Mal'sagova).

The assimilation of ethnic pedagogical knowledge is achieved by analysing scientific works and their practical application in the process of ethnic pedagogical education, which requires the organization of scientific and methodological support. Ethnic pedagogization is viewed as "the main and decisive factor in the integration of education and up-bringing" (Volkov, 2003: 4-7).

In identifying the content of ethnic pedagogical knowledge, it is important to study the theoretical foundations of ethnic pedagogy and the essence of folk pedagogy, as well as the ethnic values of culture, revealed in the works of historical and cultural nature. Ethnic pedagogical knowledge has an interdisciplinary connection with general pedagogy, history of pedagogy and education, cultural studies, ethnography, psychology and other sciences, which proves the depth, breadth and completeness of the content of ethnic pedagogy. The practice-oriented content of ethnic pedagogy shows that one of the main goals of introducing elements of folk pedagogy into the content of education is the transfer of folk knowledge on education in ethnocultural traditions and folk art. According to N.S. Chernyakova, "tradition as the transmission of sociocultural experience from one generation to another is the main mode of existence 
and development of culture. One of the most important elements of the heritage of modern cultural subjects is the knowledge obtained from previous generations, which forms the foundation for the further development of culture" (Chernyakova, 2016: 6063). In the methodology of pedagogy it is outlined: “...knowledge is complete when it reveals the objects and phenomena of reality "in their real life", in the unity of their parts..." (Kraevskii, 2001).

In pedagogical research, the identification of various aspects of ethnic pedagogical knowledge in conjunction with the aspects of ethnic culture remains relevant. In accordance with the tasks of education of the Russian Federation at the present stage, the trend of ethnic pedagogization of education and expansion of research in the field of ethnic pedagogy is preserved (Sh.M.Kh. Arsaliev, M.V. Markhieva, Sh.M. Mukhtarova, G.V. Nezdemkovskaya, V.A. Nikolaev, R.G. Pavlidi, N.M. Stukalenko and others). Thus, V.A. Nikolaev in his article outlines the main statements of ethnic pedagogy. According to the researcher, "the establishment of ethnic pedagogical knowledge supposes determining of subjects of folk education, their function and role and training of next generation" (Nikolaev, 2013: 47).

Ethnic pedagogical research allows revealing and studying ethnic pedagogical knowledge and expansion of its content, generally aimed at solving a number of tasks:

- understanding the elements of ethnic pedagogical knowledge in the empirical educational experience of the people, identifying and studying the objective scientific and practical prerequisites for the emergence of ethnic pedagogical knowledge (anthropological, socio-economic, cultural, ethnological, historical and pedagogical, etc.);

- identification of the content of ethnic pedagogical knowledge; analysis and synthesis of concepts included in the content of ethnic pedagogical knowledge and their comparison;

- disclosure of patterns of ethnic pedagogical knowledge, as well as its forms;

- understanding the content of ethnic pedagogical knowledge in conjunction with the knowledge of ethnic culture;

- a comparative analysis of the content of ethnic pedagogical knowledge in the culture of different nations and their cognitive and educational significance.

Each of the designated tasks, in our opinion, is taken into account in the process of ethnic pedagogization, which is also typical for education in the Republic of Tyva. Ethnic pedagogization and expansion of the content of ethnic pedagogical knowledge are interdependent with the development of ethnic pedagogical knowledge 
in Tuvinian culture in the research of K.B. Salchak, Kh.D.-N. Oorzhak, A.S. Shaaly and others, as well as with the research and development of teaching materials on the introduction of elements of folk pedagogy in educational institutions of Tuva (G.D. Sundui et al.). Methodological materials are being developed, the experience of individual secondary schools of Tuva in introducing elements of folk pedagogy into the process of training and education is summarized. The media highlights the experience of educational institutions, individual teachers, as well as the experience of family education of residents of the republic. The programme "Ancient customs and traditions of the Tuvinian people" (created by a group of workers of the Ministry of Education of the Republic of Tyva) and the manual "Uluschu uzhurlar" (Folk traditions) are methodologically relevant to the requirements of empirical research. As well as the handbook "Our Family" (a team of authors of the school No. 5 in Kyzyl) published by the gymnasium No. 9 in Kyzyl (A.K. Oorzhak). The manuals on the spiritual and moral education of pupils of secondary school No. 2 of the city of Turan were developed by O.M. Damchay, E.S. Ondar (as a result of many years of experimental work of the school team).

The introduction of folk pedagogy elements in education in Tuva enhanced the study of ethnic pedagogy in the context of higher education. The manual "Traditional culture of Tuvinians" (A.K. Kuzhuget, I.V. Podik), the programme of the special course "Tuvinian folk pedagogy in the training of future teachers" (T.T. Munzuk), educational and methodical complex "Ethnic pedagogy" (A.S. Shaaly), an educational manual on ethnic pedagogy (S.Ya. Oorzhak) remain relevant. In general, the analysis of the literature for secondary schools and higher educational institutions shows that there are the methodological foundations, goals, objectives and content in any aspect of ethnic pedagogical research. In empirical terms, it relates mainly to the role of the family in the moral education of schoolchildren. Theoretically, researchers carry out the analysis of works from different areas of knowledge about traditions and customs in Tuvinian culture.

At the modern stage of development the education in Tuva needs research on introduction of the elements of folk pedagogy in preschools (B.V. Salchak, Ch.M. Ondar, El.E. Mendot). They are unified by the objective of enhancing the interest of the next generation to folk knowledge about the environment, traditional standards of behaviour and folk art, folk games and festivals, myths and legends.

It still remains relevant that theoretical and practically oriented ethnic pedagogical knowledge in general show the level of ethnic pedagogical culture. Ethnic pedagogical 
knowledge should be studied in the process of ethnic pedagogization of education, which influences the development of general and ethnic pedagogical culture in particular.

As education in the republic is developing in accordance with the state educational standards, modern information technologies and available published information create favourable education conditions for the next generation of the Republic of Tyva. Enculturation is performed taking into account that certain regions of the republic have a mono-ethnic composition of the population. It is important to understand the ethnic culture and its role in the process of ethnic pedagogization. Studies of childhood subcultures, youth subcultures, transformational changes in the culture of the peoples of Russia show, for example, that "... we must always remember (and take into account) that the child's primary socialization occurs in the world of a particular ethnic culture and that it exists (at the same time) among other ethnic cultures" (Kopeikina, 2000: 23-24).

In the conditions of higher education in Tuva, the importance of organizing students' research work on the study of folk knowledge is emphasized, along with psychological and pedagogical research, based on cultural and historical publications. Empirical and theoretical materials reflecting the people's knowledge of Tuvinians about educating the younger generation, their scientific analysis allow us to develop questions of expanding the content of ethnic pedagogical knowledge on the materials of the Republic of Tyva in accordance with the basic concepts of Tuvinian folk pedagogy, the content of which reflects people's knowledge about human education.

The main statement of the research is that the notion "ethnic pedagogical knowledge" is an integral basis of ethnic pedagogical research.

Understanding of the content of ethnic pedagogical knowledge is carried out in the process of analysis of ethnic pedagogical studies, theoretical works, conceptual foundations of ethnic pedagogy. Scientific and methodological support is achieved by a synthesis of empirical materials (in our studies, for example, on materials from the Republic of Tyva). The means of scientific and methodological support also include the compilation of a glossary, handbooks, dictionaries, bibliographic manuals. Regions of our country are actively working in this direction (Bashkortostan, Buryatia, Tatarstan, Chuvashia and others). The pedagogical support of the knowledge base for the formation of ethnic pedagogical culture in the conditions of higher education in Tuva is carried out through the development of scientific and methodological materials to help understanding of national knowledge on education. The materials are developed 
in Tuvinian and Russian. In the process of ethnic pedagogization of education, it is important to maintain a purposeful organization of the educational process and research work. In the conditions of higher education of the republic, there is a need for generalization and scientific analysis of publications of ethnic pedagogical content.

\section{References}

Chernyakova, N.S. (2016). O soderzhanii poniatiia "znanie" [On the meaning of the concept "knowledge"]. In Znanie [Knowledge], 8-2 (37), 60-63.

Kopeikina, E.Yu. (2000). Subkul'tura detstva [Subculture of childhood]. Author's abstract of the thesis for the Degree of Candidate of Cultural Studies. Nizhny Novgorod, $31 \mathrm{p}$.

Kraevskii, V.V. (2001). Metodologiia pedagogiki: posobie dlia pedagogovissledovatelei [Methodology of pedagogy: guide for teachers-scholars]. Cheboksary, Publishing House of Chuvash University, $244 \mathrm{p}$.

Mal'sagova, M.Kh. (2014). Metodologiia etnopedagogicheskogo issledovaniia [Methodology of ethnic pedagogical research]. Author's abstract of the thesis for the Degree of Candidate of Pedagogy. Pyatigorsk, available at: http:/nauka-pedagogika. com/viewer/584664/a\#?page=1

Nezdemkovskaya, G.V.(2011a). Stanovlenie etnopedagogiki Rossii [Development of ethnic pedagogy in Russia]. Available at: https://cyberleninka.ru/article/v/stanovlenieetnopedagogiki-v-rossii

Nezdemkovaskaya, G.V. (2011b). Etnopedagogika [Ethnic pedagogy]. Student's manual for higher educational institutions. Moscow, Akademicheskii proekt; AlmaMater, 225 p. (Caudeamus).

Nikolaev, V.A. (2013). Vedushchie polozheniia etnopedagogiki [Leading statements of ethnic pedagogy]. In Pedagogika [Pedagogy], 4, 41-49.

Shtykareva, V.Yu. (2005). Didakticheskie osnovy etnopedagogicheskoi podgotovki budushchego uchitelia v obrazovatel'nom prostranstve vuza [Didactic basis of ethnic pedagogical training of a future teacher in the educational space of a university]. Petrozavodsk. Available at: http://nauka-pedagogika.com/pedagogika-13-00-08/ dissertaciya-didakticheskie-osnovy-etnopedagogicheskoy-podgotovki-buduschegouchitelya-v-obrazovatelnom-prostranstve-vuza

Volkov, G.N. (2003). Etnopedagogizatsiia - glavnyi i reshaiushchii faktor integratsii obucheniia $\mathrm{i}$ vospitaniia [Ethnic pedagogization as the main and decisive factor in the integration of training and education]. In Etnopedagogizatsiia 
tselostnogo uchebno-vospitatel'nogo protsessa: Materialy Vserossiiskoi nauchnoprakticheskoi konferentsii [Ethnic pedagogization of the whole educational process: Materials of the All-Russian Scientific and Practical Conference]. Yoshkar-Ola, Mariisky Institute of Education, 4-7.

\section{Этнопедагогическое знание}

(расширение содержания

на материалах Республики Тыва)

С.Я. Ооржак, Х.Д.-Н. Ооржак

Тувинский государственный университет Россия, 667000, Республика Тыва, Кызыл, ул. Ленина, 36

$\overline{Э т н о п е д а г о г и ч е с к о е ~ з н а н и е ~ в ~ с в о е м ~ с о д е р ж а н и и ~ о х в а т ы в а е т ~ к о м п л е к с ~ з н а н и и ̆ ~ в ~ о б-~}$ ласти этнопедагогики, начиная с ее предмета - народной педагогики и ее истоков, а также знаний в области многих дисциплин. По мнению авторов статьи, в условиях этнопедагогизащии образования Республики Тыва актуальными остаются задачи расширения содержания этнопедагогических знаний.

Ключевые слова: этнопедагогика, этнопедагогические знания, формирование этнопедагогических знаний, расширение и осмысление их содержания.

Научная специиальность: 24.00.00 - культурология. 